\title{
A study note on the state-denoting 個 ge "GE" construction
}

Niina Ning Zhang

Correspondence: Lngnz@ccu.edu.tw Graduate Institute of Linguistics, National Chung Cheng University, Chia-Yi, Taiwan, Republic of China

\begin{abstract}
This short paper investigates a colloquial construction in Mandarin Chinese in which a secondary predicate may be preceded by the enclitic ta (它 ta "it") and the classifier 個 ge "GE." The paper argues that ge heads a dependent clause, where the enclitic is the subject of the secondary predicate. Therefore, first, the classifier is not used as a counting unit in this numeral classifier language; and second, in addition to PRO, another form of the subject for a dependent clause is attested in secondary predicate construction in this language.
\end{abstract}

Keywords: Classifier; Secondary predicate; Nominalization; Subject; Proform

\section{Introduction: the state-denoting GE construction}

In this paper, I discuss the syntax of a special secondary predicate construction in colloquial Mandarin Chinese. The research goal is to report a special use of a classifier and a special use of a pronominal element. Two examples of the construction are in 1 . The state-denoting adjective 痛快 tongkuai "overjoyed" is preceded by the cluster (一)個 (yi)-ge "one GE" in both examples. In addition, the pronominal enclitic $t a$ (TAc) also precedes the cluster in 1a. The enclitic shares its form with the third person singular pronoun 她/他/它 ta "she/he/it." The optional - yi shares its form with the numeral - yi “one," and 個 ge is a classifier. I will call the construction state-denoting GE-construction (SGC henceforth). In this construction, the post-verbal string is not an argument of the verb. In 1, the verb 玩 wan "play" is unergative, taking the nominal 我們 women "we" as its unique argument ${ }^{\mathrm{a}}$.

a. 我們玩它(一)個痛快.

women_wan_ta_(yi)-ge_tongkuai. 1PL_play_TA_one-CL_overjoyed

Let's play until we are overjoyed.

b. 我們玩了(一)個痛快.

women_wan-le_(yi)-ge_tongkuai.

1PL_play-PRF_one-CL_overjoyed

We played until we were overjoyed

This construction can be compared with the following constructions, which also have TAc and a special use of the classifier ge.

(c) 2016 Zhang. Open Access This article is distributed under the terms of the Creative Commons Attribution 4.0 International License (http://creativecommons.org/licenses/by/4.0/), which permits unrestricted use, distribution, and reproduction in any medium, provided you give appropriate credit to the original author(s) and the source, provide a link to the Creative Commons license, and indicate if changes were made. 
（2） a. 我想畫它(個)三幅漫畫.

wo_xiang_hua_ta_(ge)_san_fu_manhua.

1SG_want_draw_TA_CL_three_CL_cartoon

I want to draw three cartoons.

b. 我想吃它四個肉包子.

wo_xiang_chi_ta_si_ge_rou-baozi.

1SG_want_eat_TA_four_CL_meat-steamed.dumpling

I want to eat four meat steamed dumplings.

SGCs and examples such as those in 2 share some properties. For instance, different from the personal pronoun use of 她/他/它 $t a$ “he/she/it," ta in these constructions must have a morphological host to its left, and thus, it is an enclitic (Lin and Zhang 2006: 817-818). Since TAc never initiates a clause, sentences like 3 are not acceptable. Also, like other clitics (see Klavans 1985), TAc has a categorially specified host: it takes a verb as its host (Lin and Zhang 2006: 819). Thus, it may not follow a preposition. For instance, TAc may not follow the preposition 到 dao "until" in the SGC in 4a, and the preposition 向 xiang "toward" in the non-SGC in 4b. TAc also may not follow a conjunction, such as 和 he "and," as seen in the SGC in $5 \mathrm{a}$ and the non-SGC in $5 \mathrm{~b}$.

（3） *它一個措手不及, 我想殺.

"ta_yi-ge_cuoshoubuji,_wo_xiang_sha.

TA_one-CL_unprepared_1SG_want_kill

(4) a. "吃到它個飽.

*chi_dao_ta_ge_bao.

eat_until_TA_CL_full

b. *我要向它一個人發洩一下.

"wo_yao_xiang_ta_yi_ge_ren_faxie_yixia.

1SG_want_toward_TA_one_CL_person_vent_once

（5） a. *我想殺它一個措手不及和它一個片甲不留.

"wo_xiang_sha_ta_yi-ge_cuoshoubuji_he_ta_yi-ge_pianjia-buliu.

1SG_want_kill_TA_one-CL_unprepared_and_TA_one-

CL_nothingremain

b. "我想看它三本漫畫和它四本雜誌.

"wo_xiang_kan_ta_san_ben_manhua_he_ta_si_ben_zazhi.

1SG_want_read_TA_three_CL_cartoon_and ta_four_CL

_magazine

Moreover, like other clitics, TAc is phonologically weak. It has a neutral tone (Ma 马 庆株 1983: sec. 12) and is thus never stressed, as shown by the unacceptability of 6 a and $7 \mathrm{a}$; and it never contrasts to another element in the context, as shown by the unacceptability of $6 \mathrm{~b}$ and $7 \mathrm{~b}$. 
(6) a. *玩它(一)個痛快.

"wan_ta_(yi)-ge_tongkuai (if $t a$ is stressed)

play_TA_one-CL_overjoyed

b. "我們玩它一個痛快, 不是玩一個痛快.

"wan_ta_yi-ge_tongkuai,__bu-shi_wan_yi-ge_tongkuai.

play_TA_one-CL_overjoyed_not-be_play_one-CL_overjoyed

（7） a. *我想畫它三幅漫畫.

"wo_xiang_hua_ta_san_fu_manhua. (if ta is stressed)

1SG_want_draw_TA_three_CL_cartoon

b. *我想畫它三幅漫畫, 不是三幅漫畫.

"wo_xiang_hua_ta_san_fu_manhua,__bu-

shi_hua_san_fu_manhua.

1SG_want_draw_TA_three_CL_cartoon_not-

be_draw_three_CL_cartoon

Wu and Mathews (2010: 1809) deny the clitic status of TAc, trying to give a unified analysis of TAc and all other uses of ta. Properties like these challenge their analysis and support the clitic analysis of TAc in 1 and $2^{\mathrm{b}}$.

However, SGCs are different from the constructions in 2. The right-edge expression denotes a state in the former, but an entity in the latter. Restricting my discussion to SGCs, I do not consider the latter constructions in this paper.

In an SGC, to the right of the verb, except yi "one," no real numeral may occur (e.g., Wu 2004: 33), as shown in 8. In contrast, 三 san "three" occurs in 2a and 四 si "four" occurs in 2b. Also, only the classifier ge may occur in a SGC, as shown in 9. In contrast, the classifier 幅 $f u$ occurs in 2 a.

（8）"咱們完它三個痛快.

"zanmen_wan_ta_san_ge_tongkuai.

1PL_play_TA_three_CL_overjoyed

（9）"咱們玩它一\{幅/次\}痛快.

"zanmen_wan_ta_yi_\{fu/ci\}_tongkuai.

1PL_play_TA_one_CL/CL_overjoyed

Thus, in a SGC, yi does not function as a numeral, nor does $g e$ as a counting unit.

I will introduce the secondary predicate status of the right-edge expression of a SGC in Section 2. Then, I will examine the two functional elements of the construction, (yi)-ge and TAc, in the next two sections, respectively. Section 5 concludes the paper.

\section{Secondary predication in SGCs}

In a SGC, the phrase that follows $(y i)$-ge is a secondary predicate. For instance, 新鮮 xinxian "fresh" in 10a describes the state of the patient of the verb 吃 chi "eat," and therefore, it is a patient-oriented secondary predicate. The right-edge expressions in other examples in 10 are also patient-oriented secondary 
predicates. Moreover, the expression 昏天黑地 hun-tian-he-di "dusk-sky-darkearth" in 11a describes the resultant drunk state of the agent of the verb 喝 he "drink," and therefore, it is an agent-oriented secondary predicate. The right-edge expressions in other examples in 11 are also agent-oriented secondary predicates. Furthermore, the expression 風捲殘雲 feng-juan-can-yun "wind-wrap-remainingcloud" in 12a describes the manner of the verb 吃 chi "eat," and thus, it is an event-oriented secondary predicate, assuming manners are predicates (Ernst 2002: 322; den Dikken 2006: 30). The right-edge expressions in other examples in 12 are also event-oriented secondary predicates (for more such examples, see Wu 2004: 21) ${ }^{\mathrm{c}}$.

a. 吃它一個 $\{$ 新鮮/爽口\}.

chi_ta_yi-ge_\{xinxian/shuangkou\}.

eat_TA_one-CL_fresh/delicious

Let's eat the food \{resh/delicious\}.

b. 我們可以打它一個措手不及.

women_keyi_da_ta_yi-ge_cuoshoubuji.

1PL_can_beat_TA_one-CL_unprepared

We can give them an unexpected hit.

c. 打它一個片甲不留.

da_ta_yi-ge_pianjia-buliu.

beat_TA_one-CL_nothing-remain

Let's beat them and make them have nothing left.

（11） a. 我們去喝它一個昏天黑地.

women_qu_he_ta_yi-ge _hun-tian-hei-di.

1PL_go_drink_TA_one-CL_dusk-sky-dark-earth

Let's go to drink until we get drunk.

b. 阿林想吃它一個過㾄.

a-lin_xiang_chi_ta_yi-ge_guoyin.

A-Lin_want_eat_TA_one-CL_enjoyed

$A$-Lin wants to eat until he is enjoyed.

c. 咱們看它一個飽.

zanmen_kan_ta_yi-ge_bao.

1PL_watch_TA_one-CL_full

Let's watch (e.g., movies) until we get satisfied.

（12） a. 吃了一個風捲殘雲.

chi-le_yi-ge_feng-juan-can-yun.

eat-PRF_one-CL_wind-wrap-remaining-cloud

$\{$ They/He/She/You\} ate to a clean sweep.

b. 咱們去問它一個水落石出.

zanmen_qu_wen_ta_yi-ge_shui-luo-shi-chu.

1PL_go_ask_TA_one-CL_water-fall-rock-out

Let's do a thorough interrogation until everything is clear. 
c. 吃它一個夠.

chi_ta_yi-ge_gou.

eat_TA_one-CL_enough

Eat until it should stop.

In a SGC, the category of the right-edge phrase can be a simple AP, e.g., 新鮮 xinxian “fresh" in 10a, or an idiomatic expression, e.g., 片甲不留 pianjia-buliu "nothing remain" in 10c. Such an AP and idiomatic expression can also occur in a matrix predicate, as in 13 (the idiomatic expression is not gradable, and therefore, it does not occur with a degree word):

a. 食物很新鮮.

shiwu_hen_xinxian.

food_very_fresh

The food is fresh.

b. 敵人已經片甲不留了.

diren_yijing_pianjia-buliu_le.

enemy_already_nothing-remain_PRT

The enemy has already nothing left.

\section{$3 \mathrm{GE}$ as the head of a dependent clause}

Recall that the classifier ge in a SGC does not express a counting unit (Section 1). In this section, I argue that $g e$ in a SGC realizes the head of a dependent clause, which is similar to a non-finite or nominalized clause in other languages. This word is obligatory in the construction (Wu 2004: 48 fn. 15; Lin and Zhang 2006: 803):

$$
\begin{aligned}
& \text { 咱們玩它(一)*(個)痛快. } \\
& \text { zanmen_wan_tta_(yi)-"(ge)_tongkuai. } \\
& \text { 1PL_play_TA_one-CL_overjoyed } \\
& \text { Let's play until we are overjoyed. }
\end{aligned}
$$

The element $y i$ to the left of $g e$ is optional in a SGC (Lü 吕叔湘1944 [1990]). It may not be replaced with any real numeral (Section 1), or any other word. Lü 吕叔湘 (1944 [1990: 174]) claims that in many contexts, ge is a short form of $y i-g e$ (also see Wu 2004: 48 fn. 19; Shu 2012: 672). I thus claim that yi-ge and ge are allomorphs of the same morpheme in a SGC.

I claim that (yi)-ge heads a functional projection. The structure of the post-verbal string in a SGC is 15, where (yi)-ge realizes the head of FP.

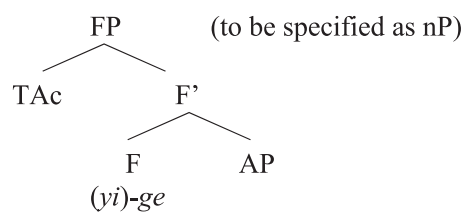

Like other head elements, $(y i)$-ge has selectional restrictions: the element to its right must be gradable, unless it is a four-morpheme idiomatic expression, such as 片甲不留 pianjia-buliu “nothing remain” in 10c. For instance, 痛快 tongkuai 
"overjoyed" in 14 is gradable and so is 開心 kaixin "happy" in 16 (regardless of whether the expressions are analyzed as adjectives or stative verbs). When the statives are used in a matrix predicate, they may occur with a degree word such as 很 hen "very" (hen tongkuai, hen kaixin).

(16) 玩個開心.

$$
\begin{aligned}
& \text { wan_ge_kaixin. } \\
& \text { play_CL__happy } \\
& \text { to play until feeling happy }
\end{aligned}
$$

The restriction, first, rules out a non-gradable stative expression, such as 累翻 lei-fan “tired-tumble," 餓昏 e-hun "hungry-faint," or 氣炸 qi-zha "angry-explode," to the right of $(y i)$-ge, as seen in 17. In no context may such words be preceded by a degree word ("hen lei-fan, "hen e-hun, "hen qi-zha) $)^{\mathrm{d}}$.

a. *他跑了個累翻.

$$
\begin{aligned}
& \text { "ta_pao-le_ge_lei-fan. } \\
& \text { bSG_run-PRF_CL_tired-tumble } \\
& \text { b. "他聽了個氣炸. } \\
& \text { "ta_ting-le_ge_qi-zha. } \\
& \text { 3SG_listen-PRF_CL_angry-explode }
\end{aligned}
$$

Second, the restriction also excludes a PP to the right of $(y i)$-ge, since a PP is not gradable. In 18a, the PP 自國外 zi guowai “from abroad" follows (yi)-ge, and the example is not acceptable. Similarly, in 18b, the PP 到天亮 dao tian liang "until day bright" follows $(y i)$-ge, and the example is not acceptable, either.

$$
\begin{aligned}
& \text { a. "來它(一)個自國外. } \\
& \text { "lai_ta__(yi)-ge_zi_guowai. } \\
& \text { come_TA_one-CL_from_abroad } \\
& \text { b. "玩它(一)個到天亮. } \\
& \text { "wan_ta_(yi)-ge_dao_tian_liang. } \\
& \text { play_TA_one-CL_until_day_bright }
\end{aligned}
$$

Now, we discuss the nature of this F in 15. First of all, the special use of (yi)-ge is not found in matrix predication ("蔬菜(一)個(很)新鮮*shucai (yi)-ge (hen) xinxian. Intended: "The vegetable is fresh"; also see Zhang 张庆文2009: (26b)). The string ta(yi)-ge-AP always expresses a secondary predication. Thus, (yi)-ge heads a dependent clause, like to in infinitives or of in a nominalization construction such as the destruction of Rome.

Moreover, $g e$ in an SGC indeed behaves like a nominalizer. If an element is used as a nominalizer, it does not license ellipsis, although it may do so in another use. In 19a, in its modification marker use, 的 de "DE" licenses the ellipsis of 方言 fangyan "dialect" in the second conjunct; but in 19b, in its nominalizer use, de does not license the ellipsis 
of 淪陷 lunxian "fall" in the second conjunct. Likewise, in 20a, in its counting unit use, ge licenses the ellipsis of 叉子 chazi "fork" in the second conjunct; but in the SGC in 20b, ge fails to license the ellipsis of 呴 gou "enough" in the second conjunct. This fact supports the nominalizer analysis of $g e$ in a SGC.

a. 他研究東北的方言, 我研究北京的.

ta_yanjiu_dong-bei_de_fangyan,_wo_yanjiu_beijing_de.

3SG_study_east-north_DE_dialect_1SG_study_Beijing_DE

He studies the Northeast dialects, and I study the Beijing dialect.

b. *他研究東北的淪陷, 我研究北平的.

"ta_yanjiu_dong-bei_de_lunxian,_wo_yanjiu_beiping_de.

3SG_study_east-north_DE_fall_1SG_study_Peking_DE

（20）ａ. 他買了一個叉子,我也買了一個.

ta_mai-le_yi_ge_chazi,_wo_ye_mai-le_yi_ge.

3SG_buy-PRF_one_CL_fork_1SG_alsobuy-PRF_one_CL

He bought a fork, and so did I.

b. *他要玩一個夠,我也要玩一個.

"ta_yao_wan_yi-ge_gou,_wo_ye_yao_wan_yi-ge.

3SG_want_play_one-CL_enough _1SG_also_want_play_one-CL

In the language, a secondary predicate may also be introduced by the functional element 得 $d e$ “DE," as seen in 21 .

a. 你吃得很痛快.

ni_chi_de__hen_tongkuai.

2SG_eat_DE_very_overjoyed

You ate very overjoyed.

b. 你吃得痛不痛快?

Ni_chi_de_tong-bu-tongkuai?

2SG_eat_DE_overjoyed-not-overjoyed

Did you feel overjoyed in your eating?

The post-de secondary predicate is represented by a full clause, a CP (Li 1999). In contrast, the post-verbal string in a SGC is not a full clause. Instead, it behaves like a nominalized structure, since it is subject to certain constraints on nominalization in the language: the degree word hen "very," which heads a DegreeP (Zhang 2015), and the A-not-A question form may not occur in the nominalization domain ( $\mathrm{Fu}$ 1994; Fu et al. 2001). For instance, hen is banned to the right of $(y i)-g e$, as seen in 22a (Wu 2004: 24; Lin and Zhang 2006: 802; Shu 2012: 685). Moreover, the predicate following (yi)-ge may not have an A-not-A form, as shown in 22b (Wu 2004: 25, 31). The ungrammaticality of the examples in 22 is compared with the grammaticality of the de constructions in 21 . Since the post-de part is a CP (Li 1999), rather than a nominalized expression, it is not subject to the constraints that are found in nominalized expressions. 


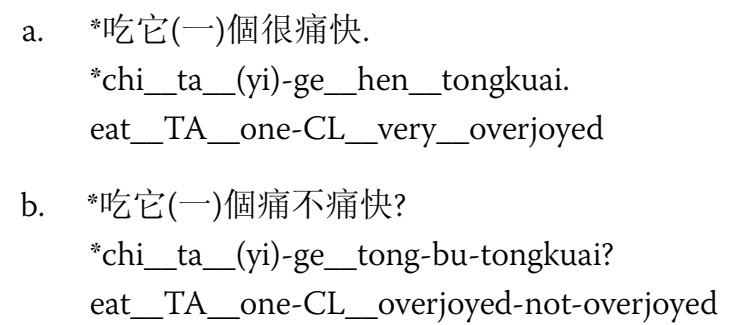

We conclude that a SGC contains a nominalized secondary predication structure, different from the de-type of secondary predication syntactically (contra Shao 邵 敬敏1984 and Zhang 张庆文2009: 19) ${ }^{\mathrm{e}}$. In English, in addition to a full CP that is introduced by words such as such that, non-finite forms, such as infinitives and nominalization constructions, also express a dependent predication. In Chinese, the default classifier ge (or its morphological variant $y i$-ge) may have the function of a nominalizer (see Myers 2000 for ge's special status even when it occurs as a counting unit). Since classifiers in numeral classifier languages may have various uses (Bisang 1999), this use of ge is not surprising.

Therefore, FP in 15 can be specified as nP. The structure is compatible with Bresnan (1997), and Borsley and Kornfilt's (2000) claim that nominalization of XP is represented by the merger of XP with a nominal functional head, such as $\mathrm{n}$. Also, the word of in an of-nominalization expression (e.g., the development of the country) is obligatory; and similarly, (yi)ge in a SGC is obligatory. On the other hand, in examples like 2a, where the right-edge phrase is already a nominal, $g e$ is not obligatory.

Having established that $(y i)$-ge heads an $\mathrm{nP}$ and takes the secondary predicate as its complement in a SGC, I now turn to my analysis of TAc in the construction.

\section{TAC as an overt subject of a dependent clause in a SGC}

Various analyses of TAc have been proposed in the literature. But these analyses are proposed for constructions such as those in 2, where the post-verbal string initiated by TAc looks like an object of the preceding verb. For instance, Lin (1994) and Wu and Matthews (2010) claim that TAc is an object expletive (AgrOP expletive in Lin's term), and Lin and Zhang 2006 claim that it is a D-element. The SGCs discussed in this paper are semantically and syntactically different from the constructions such as those in 2 (see Section 1). Crucially, the verb of a SGC can be unergative, such as 玩 wan "play." There is no argument position for the assumed DP. Therefore, in a SGC, neither the whole post-verbal string nor any part of it is an object of the verb, and thus, neither definiteness features nor any other formal features of an object occur in the post-verbal elements. Consequently, these analyses do not apply to SGCs. In this section, I discuss the syntactic position and syntactic function of TAc in a SGC, showing that it is the subject of the secondary predicate.

\subsection{The syntactic position of TAC}

I have argued that in a SGC, the right-edge phrase is a secondary predicate, which is hosted by an $\mathrm{nP}$ that is headed by $(y i)$-ge. I now further claim that TAc 
is in the subject position of this predication, occurring at the Spec of nP. In this perspective, the $\mathrm{nP}$ is one instance of the general predication-denoting projection, such as Bowers's (1993) PredP or den Dikken's (2006) RP. In such a projection, the Spec is the position of a subject and the complement is the position of a predicate.

In 15, TAc and (yi)-ge have a Spec-head relation. If two elements are in a Spec-head relation, no element may intervene. Indeed, no element, such as the determinative degree word name "that degree," may occur between TAc and (yi)-ge in a SGC, as shown in 23.

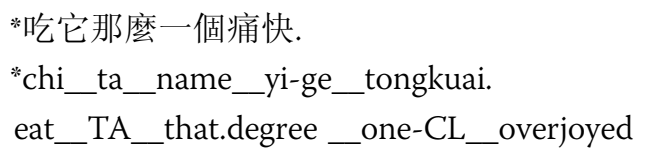

This adjacency relation also rules out a topic analysis of TAc. In the embedded sentence of $24 \mathrm{a}$, the embedded subject, the pronoun 他 $t a$ "he," is followed by the topic marker 呀 ya. In the SGC in 24b, however, TAc may not be followed by $y a$.

a. 我聽說他呀根本是一個書呆子.

wo_tingshuo_ta_ya_genben_shi_yi_ge_shudaizi.

1SG_hear_3SG_TOP_just_be_one_CL_bookworm

I heard that he is just a bookworm.

b. 吃它("呀)一個痛快.

chi_ta_("ya)_yi-ge_tongkuai.

eat_TA_TOP_one-CL_overjoyed

Eat until you are overjoyed.

In the examples in 25 , the bracketed part is nominalized by the element de. One can see that this part may not contain a topic. This is expected, since a nominalized expression has no C-domain functional projection to host a topic (similarly, "I disapprove of such books your reading. See Hooper and Thompson 1973: 485). Thus, it is not surprising that the whole string TAc-yi-ge-XP, as a nominal, may not contain a topic.

a. 我了解[李安對㙯術的貢獻].

wo_liaojie_[li-an_dui_yishu_de_gongxian].

1SG_know_L Lee Ang_to_art_DE_contribution

I know Lee Ang's contribution to art.

b. " 我了解[(對)藝術李安的貢獻].

"wo_liaojie_[(dui)_yishu,__li-an_de_gongxian].

1SG_know_to_art_Lee Ang_DE_contribution

c. *我了解[㙯術呀李安的貢獻].

"wo_liaojie_[yishu ya,__li-an_de_gongxian].

1SG_know_art_TOP_Lee Ang_DE_contribution 
Moreover, every predicate has its subject, so does the secondary predicate of a SGC. Thus, TAc can be in a thematic position, unlike an expletive, which may surface in a nonthematic position in Icelandic or English (e.g., it in It seems that you like this paper).

Furthermore, like a subject in other constructions in the language, TAc is generally optional (Ma 马庆株1983: sec. 12). However, the overtness of the subject of the secondary predicate in SGCs is subject to certain conditions. For instance, if a verb has an aspect marker, TAc does not show up in a SGC, as shown in 26 (Lin and Zhang 2006: 819) (many more examples like 26 can be found in Lü 吕叔湘1944 [1990: 153]) ${ }^{\mathrm{f}}$.

$$
\begin{aligned}
& \text { 我們玩了("它)(一)個痛快. } \\
& \text { women_wan-le_("ta)_(yi)-ge_tongkuai. (cf. 1a) } \\
& \text { 1PL_play-PRF_TA_one-CL_overjoyed }
\end{aligned}
$$

Also, if the verb is stative, TAc does not show up, as seen in the SGC in 27 (27 is from reviewer 2; more such examples can be found in Zhang 张庆文 2009: 14) and the non-SGCs in 28 (Lin 2001, cited in Shu 2012: 669).

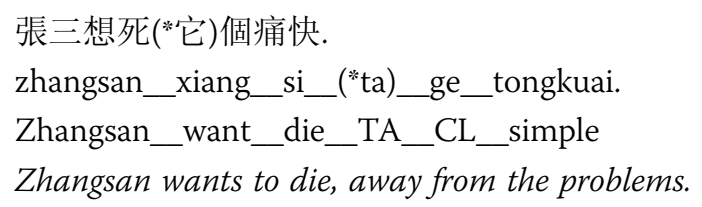

a. [懂(“它)個法文]有甚麼了不起.

[dong_("ta)_ge_fawen]_you_shenme_liaobuqi. understand_TA_GE_French_have_what_big.deal

Is it a big deal to understand French?

b. [老(“它)個幾歲]不是很重要.

[lao_("ta)_ge_ji-sui]_bu_shi_hen_zhongyao. old_TA_CL_several-year_not_be_very_important Is it a big deal to understand French?

On the other hand, as pointed out by reviewer 2, dropping of $t a$ (i.e., TAc) makes some examples such as 10c sound marginal. We also find the same effect in 10b, 11b, $12 \mathrm{a}$, and $12 \mathrm{~b}$. I leave this for future research.

\subsection{The dependent interpretation of TAC}

Semantically, TAc, as a pronominal subject of a dependent clause, has no independent referent (cf. Ma 马庆株1983: sec. 12). In 29a, the resultant state is that of A-Lin, which is an argument of the matrix predication, rather than anyone else in the discourse context. If the secondary predicate is about an event, as in 12a, it does not refer to any event other than the one that is expressed by the matrix predicate. Therefore, the interpretation of TAc is not free.

a. 阿林想吃它一個飽.

a-lin_xiang_chi_ta_yi-ge_bao.

A-Lin_want_eat_TA_one-CL_full

A-Lin wants to eat until he gets full. 
b. 我們想吃它一個飽.

women_xiang_chi_ta_yi-ge_bao.

1PL_want_eat_TA_one-CL_full

We want to eat until we get full.

Moreover, TAc occurs with a secondary predicate that is associated with any person and number, indicating that it is not specified with any $\phi$-feature value. In 29a, the state 一個飽 yi-ge bao "one CL full” is associated with 阿林 “a-lin" A-Lin, a third person singular nominal; but in $29 \mathrm{~b}$, the same state is associated with the first person plural 我們 women "we." The form of TAc remains the same in these different person and number associations (Chinese nominals, including personal pronouns, have no morphological gender contrast).

Furthermore, TAc may not be replaced with another pronoun such as 你 $n i$ "you" or 我 wo “I/me" (Ma 马庆株 1983: sec. 12), or any other element, including 自己 ziji "self," which is also underspecified with $\phi$-feature values, as shown in 30a, or an expression such as 他們兩個人 tamen liang ge ren "they two," as shown in 30b:

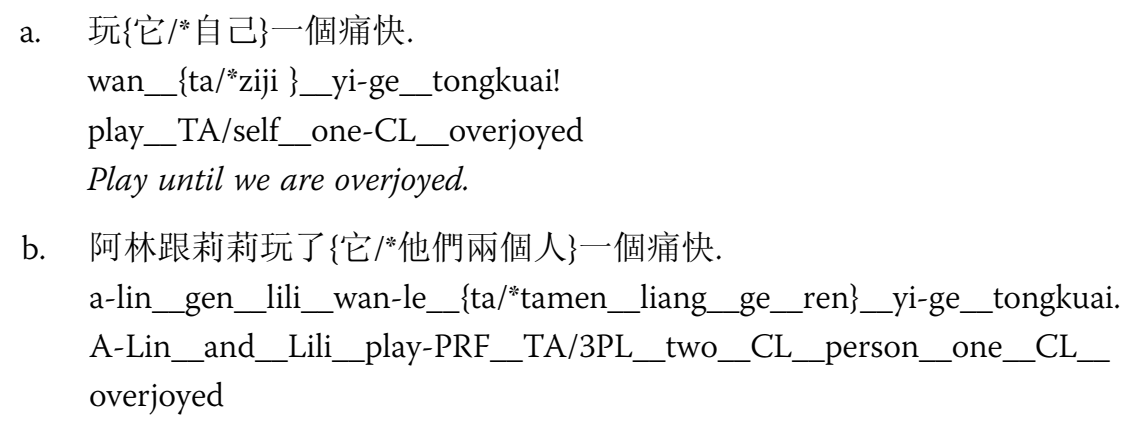

A-Lin and Lili played until they were overjoyed.

We have argued that TAc occurs in the subject position of a dependent predication. The above facts show that the interpretation of the enclitic is dependent on the matrix clause, similar to that of a PRO. It is well-recognized that PRO occurs in the subject position of a dependent clause only. Moreover, for a non-arbitrary PRO, it takes either an individual-denoting nominal of the matrix clause, or an event-denoting matrix clause, as its antecedent. When it takes an individual-denoting nominal as its antecedent, the antecedent may have any $\phi$-features. In Hornstein and Lightfoot (1987), Larson (1991), and Bowers (1993), the silent subject of a resultative or depictive is analyzed as a PRO, and its antecedent is an argument of the matrix predication. For instance, the subject of clean in 31a is a PRO, whose antecedent is the table, the object of wiped. Similarly, the subject of raw in 31b is a PRO, whose antecedent is the fish, the object of ate. Williams $(1974 ; 1985$ : 308) also shows that "the matrix S itself is available as a controller of the result clause." One of his examples is 31c. In this case, the antecedent of the PRO is the whole event-denoting matrix clause.
a. John wiped the tablei [PROi clean].
b. John ate the fishi [PROi raw].
c. [John went to New York]i [PROi to annoy Mary]. 
Thus, it is plausible that TAc, as a pronominal subject of a secondary predicate, takes an implicit or explicit argument of the matrix clause, or the event expressed by the matrix clause, as its antecedent. Therefore, the interpretation of TAc depends on the matrix clause. For instance, the antecedent of TAc in 30a is the agent of the matrix verb wan "play," which is a pro.

In this analysis, TAc looks like an overt PRO. Cross-linguistically, the position of PRO may indeed be filled by an overt form, such as a special form of a pronoun or a reflexive. See Borer (1989), Szabolcsi (2009), Lee (2009), and Landau (2015: 80) for examples and discussion.

The subject position and dependent reading also distinguish TAc from the use of 你 $n i$ “you" in examples like 32 .
a. 殺你個片甲不留.
sha_ni_ge_pianjia-buliu.
kill_2SG_CL_noting-remain
A: $\{W e / I\}$ will attack you such that you have nothing left.
B: Someone will attack others such that the latter has nothing left.
b. 他要殺你個片甲不留,而不是殺我個片甲不留.
ta_yao_sha_ni_(ge_pianjia-buliu),_er-bushi_sha_wo_ge_
3SG_want_kill_2SG_CL_noting-remain _but-not_kill_1SG_CL_
pianjia-buliu.
noting-remain
He wants to attach you, but not me, such that you have nothing left.

Two facts indicate that 你 $n i$ "you" in 32 is the object of the verb 殺 sha "kill," rather than the subject of the secondary predicate. First, as shown in 7 above, TAc does not contrast with any element in the context, showing that it is a pronominal subject of the dependent clause. However, 你 $n i$ "you" contrasts with 我 wo "I" in 32b. Second, if the verb in a SGC has no object, 你 $n i$ "you" may not occur. In 33, the closest verb to the secondary predicate is the unergative verb 玩 wan "play." We can see that ni may not occur there (also see 30). If the occurrence of 你 $n i$ "you" requires the verb to be transitive, the hypothesis that it is the object of the verb is supported.

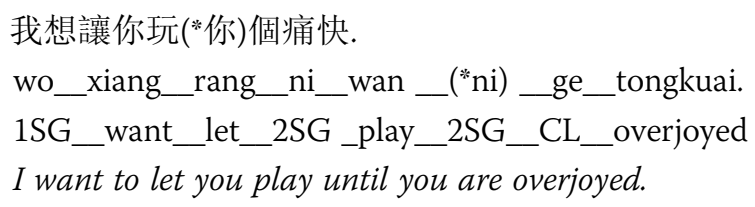

We thus claim that 你 $n i$ “you" in 32 is the internal argument of 殺 sha "kill." In $32 \mathrm{~b}$, it refers to the addressee exclusively, but in 32a, it may also have a generic use (i.e., Reading B; see Chao 1968: 648). As for the subject of 片甲不留 pianjia-buliu, it is null. TAc may not occur there because its cliticalization on the verb is blocked by the object 你 $n i$ “you." 


\section{Summary}

Summarizing, in this paper, I have argued that in a SGC, the right-edge phrase is a secondary predicate, and its possible overt subject is TAc. The dependent predication is represented by a nominal functional projection, headed by (yi)-ge. For this type of dependent predication, TAc is the only possible overt form of the subject. As an enclitic that takes a verb as its morphological host, TAc never initiates a clause, and it does not follow any element other than a verb.

Having argued for the syntactic status of each component of the post-verbal string of a $\mathrm{SGC}$, i.e., the $\mathrm{nP}$ in 15 , I now briefly address the issue how the $\mathrm{nP}$ is integrated into the structure of the whole sentence. The way of the integration depends on the semantic type of the secondary predicate expressed. It is generally assumed that a depictive is hosted by an adjunct of the matrix predicate, whereas a resultative is hosted in the complement of matrix verb (Bowers 1993, Hornstein and Lightfoot 1987, Larson 1991, among others). Under this assumption, I claim that for a non-resultative secondary predicate, the $\mathrm{nP}$ in 15 is adjoined to the structure of the matrix predicate. I leave the exact merging position vague here, since it is not crucial for the purpose of this paper. As for a resultative, one analysis is Ramchand (2008), in which an event structure has three major projections: InitiationP, where an agent or causer is hosted, ProcessP, where a patient is hosted, and ResultP. The last one encodes the resultative predication. The three projections are semantically parallel to Moens and Steedman's (1988) preparatory process, culmination, and consequence state, respectively. Accordingly, for instance, 34a should have the structure in 34b, before any movement operation is implemented. In this example, the patient of the verb 打 $d a$ "beat" is a pro (or an implicit internal argument), which is also the antecedent of $t a$.

a. 打它一個片甲不留.

da_ta_yi-ge_pianjia-buliu.

beat_TA_one-CL_nothing-remain

Let's beat them such that they have nothing left.

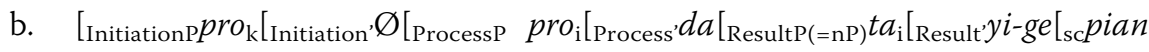
jia-buliu]]]]]]]

This paper shows that in addition to the counting unit use, the default classifier ge can also be used to head a nominal functional projection that encodes a secondary predication. We thus find a special strategy of nominalization in a numeral classifier language.

\section{Endnotes}

aAbbreviations: CL: classifier; DE: modification/nominalization marker; EXP: experiential aspect; GE: the classifier ge in a SGC; PRF: perfective aspect; PRT: sentence-final particle; SGC: state-denoting ge construction; TAc: pronominal enclitic ta; TOP: topic.

${ }^{\mathrm{b}}$ Both SGCs and other TAc constructions may have an irrealis reading, as in 1a and 2 , or realis habitual reading, as in $1 \mathrm{~b}$ and (i), in the absence of an aspect marker ((ia) is cited from Lin and Zhang 2006: 807).

a. 以前每天晚上我都要看它幾本雜誌. yiqian_meitian-wanshang_wo_dou_yao_kan_ta_ji_ben_zazhi. before_every-evening_1SG_all_would_read_TA_several_CL_magazine In the past, I read several magazines every evening. 
b. 以前我們每天都去海邊玩它個痛快.

yiqian_women_mei-tian_dou_qu_haibian_wan_ta_ge_tongkuai.

before_1PL_every-day_all_go_beach_play_TA_CL_overjoyed

Every evening in the past, we went to the beach to play until we were overjoyed.

${ }^{c}$ A durative can be a matrix predicate (Teng 1975, Ernst 1987), as in (i). It can also be an event-oriented secondary predicate. In (ii), 幾分鐘 ji fenzhong "several minutes" can be a secondary predicate of the matrix predicate 休息 xiuxi "rest" (cited from Lin and Zhang 2006: 802 (9a), also their (9b) and (4b)). As in 2a, where the right-edge phrase is a nominal, $g e$ is not obligatory in (ii).

(i)

他來美國有兩年了.

ta_lai_Meiguo_you_liang_nian_le.

3SG_come_America_have_two_year_PRT

It has been two years since he came to America.

(ii)

咱們就在這兒休息它(個)幾分鐘吧.

zamen_jiu_zai_zher_xiuxi_ta_(ge)_ji_fenzhong_ba.

1PL_right_at_here_rest_TA_CL_several_minute_PRT

We'll just rest here for a while.

${ }^{\mathrm{d}}$ I thank reviewer 1 for giving me the example in $17 \mathrm{a}$ and encouraging me to think about the issue.

${ }^{\mathrm{e}}$ If $d e$ precedes $g e$, as in (i), it is a phonological variant of the perfective marker le (cf. Zhang 张庆文2009: fn. 11). Since TAc in a SGC rejects le (4.1), it never occurs with this de. Also, this de never occurs with $y i$, as seen in (ii).

(i) 老李吃得(*它)個心滿意足.

(ii) 老李吃 $\{$ 了 $/ *$ 得 $\}$ 一個心滿意足.

laoli_chi-de_("ta)_ge_xinmanyizu. laoli_chi-\{le/*de\}_yi-ge_ xinmanyizu. LaoLi_eat-DE_TA_CL_satisfied LaoLi_eat-PRF/DE_one-CL_satisfied LaoLi ate until he was satisfied. LaoLi ate until he was satisfied.

${ }^{\mathrm{f}}$ However, in a non-SGC, TAc may follow the aspect marker -le:

$$
\begin{aligned}
& \text { 阿林一口氣就買了它三件䙬衫. } \\
& \text { a-lin_yikouqi_jiu_mai-le_ta_san_jian_chenshan. } \\
& \text { A-Lin_at.one.time_just_buy-PRF_TA_three_CL_shirt }
\end{aligned}
$$

A-Lin bought three shirts at one time.

Competing interests

The author declares no competing interests.

\section{Acknowledgements}

My thanks go to the two anonymous reviewers for their very helpful suggestions and criticisms, and to Li-Ching Chiu, Shih-Peng Shih, Yi-Ling Su, Sam Wang, and Adam Zheng for their comments on early versions of this paper. All remaining inadequacies are mine. This work has been supported by the grant MOST-103-2410-H-194-035-MY2, the Ministry of Science and Technology of Taiwan, ROC.

Received: 16 July 2015 Accepted: 16 February 2016

Published online: 04 April 2016

References

Bisang, Walter. 1999. Classifiers in East and Southeast Asian languages: Counting and beyond. In Numeral types and changes worldwide, ed. Jadranka Gvozdanović, 113-185. Berlin and New York: Mouton de Gruyter.

Borer, Hagit. 1989. Anaphoric AGR. In The null subject parameter, ed. Jaeggli Osvaldo and Kenneth J. Safir, 69-109. Dordrecht, the Netherlands: Kluwer Academic Publishers.

Borsley, Robert, and Kornfilt Jaklin. 2000. Mixed extended projections. In Syntax and semantics 32: The nature and function of syntactic categories, ed. Robert D. Borsley, 101-131. New York: Academic. 
Bowers, John. 1993. The syntax of predication. Linguistic Inquiry 24(4): 591-656.

Bresnan, Joan. 1997. Mixed categories as head sharing constructions. In Proceedings of the LFG ' 97 Conference, ed. Miriam Butt and Tracy Holloway King. Available at http://cslipublications.stanford.edu/LFG/2. Accessed 3 December 2015.

Chao, Yuan Ren. 1968. A grammar of spoken Chinese. Berkeley, CA: University of California Press.

den Dikken, Marcel. 2006. Relators and linkers: The syntax of predication, predicate inversion, and copulas. Cambridge, MA: MIT Press.

Ernst, Thomas. 1987. Durational adverhials and Chinese phrase structure. Journal of Chinese Language Teachers Association 22(2): 1-I 1.

Ernst, Thomas. 2002. The syntax of adjuncts. Cambridge, UK: Cambridge University Press.

Fu, Jingqi. 1994. On deriving Chinese derived nominals: Evidence for V-to-N raising. PhD dissertation. Amherst, MA: University of Massachusetts at Amherst.

Fu, Jingqi, Thomas Roeper, and Hagit Borer. 2001. The VP within process nominals: Evidence from adverbs and the VP anaphor do-so. Natural Language and Linguistic Theory 19(3): 549-582.

Hooper, Joan, and Sandra Thompson. 1973. On the applicability of root transformations. Linguistic Inquiry 4(4): 465-497.

Hornstein, Norbert, and David Lightfoot. 1987. Predication and PRO. Language 63(1): 23-52.

Klavans, Judith L. 1985. The independence of syntax and phonology in cliticization. Language 61(1): 95-120.

Landau, Idan. 2015. A two-tiered theory of control. Cambridge, MA: MIT Press.

Larson, Richard. 1991. Some issues in verb serialization. In Serial verbs: Grammatical, comparative and cognitive approaches, ed. Claire Lefebvre, 185-210. Amsterdam: John Benjamins.

Lee, Kum Young. 2009. Finite control in Korean. PhD dissertation. lowa, IA: University of lowa.

Li, Yafei. 1999. Cross-componential causativity. Natural Language and Linguistic Theory 17(3): 445-497.

Lin, Jo-wang. 1994. Object non-referentials, definiteness effect and scope interpretation. In Proceedings of North Eastern Linguistic Society 24, University of Massachusetts, Amherst, ed. Merce Conzalez, 287-301. Amherst, MA: University of Massachusetts.

Lin, Jo-wang, and Niina Ning Zhang. 2006. The syntax of the non-referential TA 'it' in Mandarin Chinese. Language and Linguistics 7(4): 799-824.

Lin, Tzong-hong Jonah. 2001. Light verb syntax and the theory of phrase structure. PhD dissertation. Irvine, CA: University of California.

Lü, Shuxiang 吕叔湘. 1944. The application scope of ge and the deletion of yi before the unit word 个字的应用范围, 附论单位词前一字的脱落. Papers on Chinese grammar《汉语语法论文集(增订本)》, 145-175. Beijing: The Commercial Press. 1990.

Ma, Qingzhu 马庆株. 1983. Constructions with double objects in modern Chinese 现代汉语的双宾语构造. Essays on Linguistics 语言学论丛 10: 166-196. Beijing: The Commercial Press.

Moens, Marc, and Mark Steedman. 1988. Temporal ontology and temporal reference. Computational Linguistics 14(2): 15-28.

Myers, James. 2000. Rules vs. analogy in Mandarin classifier selection. Language and linguistics 1(2): 187-209

Ramchand, Gillian Catriona. 2008. Verb meaning and the lexicon: A first phase syntax. Cambridge, UK: Cambridge University Press.

Shao, Jingmin 邵敬敏. 1984. An analysis of the verb + ge + adjective structure 动 + 个+形结构分析. Chinese Language Learning 汉语学习 2: 50-54.

Shu, Chih-hsiang. 2012. Towards a morphosyntactic analysis of Mandarin mood/aspect marker ge. Language and Linguistics 13(4): 663-692.

Szabolcsi, Anna. 2009. Overt nominative subjects in infinitival complements: Data, diagnostics, and preliminary analyses. In NYU Working Papers in Linguistics, Vol. 2: Papers in Syntax, ed. Irwin Patricia and Maldonado Violeta Vasquéz Rojas. New York: NYU.

Teng, Shou-hsin. 1975. Predicate movements in Chinese. Journal of Chinese Linguistics 3(1): 60-75.

Williams, Edwin. 1985. PRO and subject of NP. Natural Language and Linguistic Theory 3(3): 297-315.

Wu, Xiu-Zhi Zoe. 2004. Grammaticalization and language change in Chinese: A formal view. London: Routledge.

Wu, Yicheng, and Stephen Matthews. 2010. How different are expletive and referential pronouns? A parsing perspective. Lingua 120(7): 1805-1820.

Zhang, Niina Ning. 2015. Functional head properties of the degree word hen in Mandarin Chinese. Lingua 153: 14-41.

Zhang, Qingwen 张庆文. 2009. The grammatical status of ge in the V+ge+XP construction V+个+XP 结构中个的语法 地位. Modern Foreign Languages 现代外语 32(1): 13-22.

\section{Submit your manuscript to a SpringerOpen ${ }^{\circ}$ journal and benefit from:}

- Convenient online submission

- Rigorous peer review

- Immediate publication on acceptance

- Open access: articles freely available online

- High visibility within the field

- Retaining the copyright to your article

Submit your next manuscript at $\gg$ springeropen.com 